\title{
PENYULUHAN MANAJEMEN PEMASARAN YANG STRATEGIS DALAM PENGEMBANGAN YAYASAN NURUL IKHSAN
}

\author{
Risza Putri Elburdah, Ugeng Budi Haryoko, Fauziah Septiani, Lucia Maduningtias, \\ Edy Krisyanto \\ Program Studi Manajemen \\ Universitas Pamulang \\ riszaputrielburdah@yahoo.com
}

\begin{abstract}
Community service (PKM) is an integral part of the Tri Dharma of Higher Education which in its implementation is inseparable from the other two dharmas, and involves all members of the academic community: lecturers, students, education staff and alumni. Through PKM the academic community can be present in the midst of the community.The location of Nurul Ihsan Foundation is sufficient to enter the village, so that not many people know of its existence. Even though the Foundation has been established since 1994. Besides educational activities (pesantren), Nurul Ihsan Orphanage also organizes skills training for foster children and the surrounding community to cultivate talents and provide them with certain skills for the future. The number of activities above, the need to continue to develop skills is a matter that has always been championed by the management of the Nurul Ihsan Orphanage Foundation and other institutions. To meet these needs, strategic marketing management counseling is carried out so that the name Nurul Ihsan Foundation is increasingly known to the wider community. It is hoped that more donors will continue to help fulfill the education of the students and orphans at the Nurul Iksan Foundation. One solution that resulted from this outreach was about marketing media and marketing personnel that must be owned by the Nurul Iksan Foundation. PKM with the title: "Counseling Strategic Marketing Management in the Development of the Nurul Iksan Foundation" in general went smoothly and impressively. The students and the foundation's management were very enthusiastic in listening to the explanation of the material provided. This is illustrated by the many questions raised and two-way discussions that occur. The enthusiasm continued when the session reviewed cases related to marketing media.
\end{abstract}

Keywords: Marketting Management, Promotion Media ,Development. 


\begin{abstract}
Abstrak
Pengabdian Kepada Masyarakat (PKM) merupakan bagian integral dari Tri Dharma Perguruan Tinggi yang dalam pelaksanaannya tidak terlepas dari dua dharma yang lainnya, serta melibatkan segenap sivitas akademika: dosen, mahasiswa, tenaga kependidikan serta alumni. Melalui PKM civitas akademik dapat hadir di tengah- tengah masyarakat. Lokasi Yayasan Nurul Ihsan yang cukup masuk kedalam perkampungan, sehingga tidak banyak masyarakat yang mengetahui keberadaanya. Padahal Yayasan ini sudah berdiri sejak tahun 1994. Disamping kegiatan pendidikan (pesantren), Panti Nurul Ihsan juga menyelenggarakan pelatihan-pelatihan keterampilan kepada anak asuh dan masyarakat sekitar guna memupuk bakat dan membekalinya dengan keterampilan tertentu untuk dimasa yang akan datang. Banyaknya kegiatan diatas, maka kebutuhan untuk terus melakukan pengembangan keterampilan merupakan hal yang senantiasa diperjuangkan oleh para pengurus Yayasan Panti Asuhan Nurul Ihsan dan lembagalembaga lainnya. Untuk memenuhi kebutuhan tersebut maka dilakukan penyuluhan manajemen pemasaran yang strategis agar nama Yayasan Nurul Ihsan semakin dikenal masyarakat luas. Harapannya semakin banyak para donatur tetap untuk membantu memenuhi pendidikan para santri dan yatim piatu pada Yayasan Nurul Iksan. Salah satu solusi yang dihasilkan dari penyuluhan ini adalah tentang media pemasaran dan tenaga pemasaran yang harus dimiliki oleh Yayasan Nurul Iksan. PKM dengan judul: "Penyuluhan Manajemen Pemasaran yang Strategis dalam Pengembangan Yayasan Nurul Iksan" secara umum berjalan dengan lancar dan mengesankan. Para santri dan pengurus yayasan sangat antusias dalam menyimak penjelasan materi yang diberikan. Hal ini tergambar dari banyaknya pertanyaan yang dilontarkan serta diskusi dua arah yang terjadi. Antusiasme pun berlanjut saat sesi mengulas kasus-kasus yangberkaitan dengan media pemasaran.
\end{abstract}

Kata Kunci: Media Pemasaran, Media Promosi, Pengembangan

\title{
A. PENDAHULUAN
}

Manajemen pemasaran merupakan salah satu aspek terpenting dalam pengembangan suatu usaha. Untuk memulai suatu usaha, pemilik membutuhkan pengetahuan yang baik dalam manajemen pemasaran. Seorang pemilik usaha harus mempunyai keterampilanketerampilan utama yang dibutuhkan dalam mengatur pemasaran, hal ini tidak dapat diserahkan begitu saja kepada orang lain. Manajemen Pemsaran Dapat juga diartikan sebagai alat untuk analisis, perencanaan, penerapan serta pengendalian suatu program dalam perusahaan yang sudah dirancang untuk menciptakan, membangun dan juga mempertahankan 
pertukaran agar bisa memberikan keuntungan. Keuntungan ini nantinya digunakan sebagai jalan untuk mencapai tujuan utama sebuah bisnis atau perusahaan. Menurut Sofjan Assauri (2013), pengertian manajemen pemasaran adalah kegiatan analisis, perencanaan, pelaksanaan, dan pengendalian berbagai program yang disusun dalam pembentukan, pembangunan, dan pemeliharaan laba hasil dari transaksi/ pertukaran melalaui sasaran pasar untuk mencapai tujuan perusahaan dalam jangka panjang.

Konsep pemasaran yang paling baik adalah dengan menjadikan konsumen sebagai prioritas utama. Itulah sebabnya mengapa dalam strategi marketing selalu mengedepankan konsumen. Dalam pemasaran biasanya konsumen dianggap raja, dan produsen adalah pelayan yang memberikan kebutuhan raja. Pelayanan produsen dilakukan dengan memberikan berbagai penawaran yang menarik, mulai dari produk terbaik hingga cara pelayanan konsumen. Fungsi pertukaran pada manajemen pemasaran terbagi menjadi dua fungsi utama, yakni fungsi pembelian dan fungsi penjualan. Lebih lanjut, fungsi pembelian berarti peran manajemen pemasaran berfungsi sebagai proses timbal balik dari aktivitas penjualan. Dengan begitu, diperlukan strategi khusus terutama pemahaman mengenai kegiatan yang dapat menarik konsumen untuk membeli. Sedangkan fungsi penjualan termasuk dalam aktivitas untuk mempertemukan penjual dan pembeli yang bisa dilakukan secara langsung maupun melalui perantara. Konsumen yang dimaksud disini adalah para donatur yang nantinya dapat menjadi donatur tetap. Citra yang baik terhadap produk dan perusahaan akan memberikan efek positif bagi perusahaan, baik dari sisi konsumen, mitra, investor, dan tenaga kerja. Pemasaran adalah ujung tombak perusahaan untuk mencapai target penjualan, kepuasan dan target keuntungan. Itulah alasannya mengapa kelangsungan perusahaan juga menjadi bagian dari tujuan manajemen pemasaran. Disamping kegiatan pendidikan (pesantren), Panti Nurul Ihsan juga menyelenggarakan pelatihan-pelatihan keterampilan kepada anak asuh dan masyarakat sekitar guna memupuk bakat dan membekalinya dengan keterampilan tertentu untuk dimasa yang akan datang.

Banyaknya kegiatan diatas, maka kebutuhan untuk terus melakukan pengembangan keterampilan merupakan hal yang senantiasa diperjuangkan oleh para pengurus Yayasan Panti Asuhan Nurul Ihsan dan lembaga-lembaga lainnya. Untuk memenuhi kebutuhan tersebut maka dilakukan penyuluhan manajemen pemasaran yang strategis agar nama Yayasan Nurul Ihsan semakin dikenal masyarakat luas. Harapannya semakin banyak para donatur tetap untuk membantu memenuhi pendidikan para santri dan yatim piatu pada Yayasan Nurul Iksan. Secara singkat kegiatan PKM ini akan menitik beratkan dalam membuat branding dan strategi pemasaran (media dan tenaga pemasaran) yang sesuai dengan kebutuhan yayasan agar dapat bertahan dalam kondisi apapun. Konsep pemasaran sosial ini terbilang lebih baru dibandingkan konsep lainnya. Selain menekankan fokus pada konsumen, konsep pemasaran sosial juga menekankan kepentingan konsumen dan masyarakat secara umum. Perusahaan yang menggunakan konsep ini akan mempertimbangkan etika dalam praktik pemasaran mereka. Tidak hanya fokus pada keuntungan, perusahaan juga akan berusaha mengimbangi kebutuhan, kepuasan, dan minat konsumen. pemasaran merupakan salah satu hal penting yang harus dilakukan ketika menjalankan sebuah usaha, baik usaha baru maupun usaha lama yang telah dirintis bertahun-tahun lamanya. Sebelum menjalankan marketing, pertama kali yang harus dilakukan adalah menentukan konsep marketing serta strategi pemasaran yang efektif dalam menjual produk kita. 
Pada umumnya, usaha kecil mempunyai anggaran pemasaran yang terbilang kecil jika dibandingkan dengan usaha berskala besar. Dengan anggaran yang minim tersebut tentunya pemilik yayasan harus lebih kreatif dalam menentukan strategi pemasaran yang tepat. Salah satu cara yang dapat dilakukan dalam mengoptimalkan pemasaran meskipun dengan dana yang terbatas adalah dengan Melakukan kerja sama dengan pengusaha atau rekan dalam pemasangan iklan, seperti mengirimkan penawaran produk kepada para pelanggan atau memberikan potongan harga bagi pembelian paket tertentu. Memperkenalkan produk dan usaha melalui beberapa media gratis. Hal ini bertujuan untuk membantu pencarian para konsumen mengenai produk apa saja yang Anda tawarkan, seperti publikasi melalui internet dengan melibatkan lingkungan yang berada di sekitar usaha.

\section{B. METODE PELAKSANAAN KEGIATAN}

Pelaksanaan pengabdian kepada masyarakat ini dilakukan pada Yayasan Nurul Ihsan yang bertempat pada Kp. Momonggor RT $01 \mathrm{Rw} 001$ Kel. Keranggan. Pada tanggal pelaksanaan 15 - 18 Januari 2020. Peserta dan sasaran pada pengabdian kepada masyarakat ini adalah para santri dan pengurus dan pengelola Yayasan Nurul Ihsan. Metode kegiatan yang dilakukan dimulai dengan melakukan Survei di Yayasan Nur Ikhsan untuk mengetahui kondisi terkini, memberikan sosialisasi atau PKM di Yayasan Nur Ikhsan agar dapat memahami dan terealisasikan, memberikan pelatihan dan arahan yang bermanfaat bagi Yayasan Nur Ikhsan, yang dirinci dengan tahapan sebagai berikut :

1. Penyuluhan,sebagai upaya penyadaran tingkat pemahaman terhadap konsep manajemen strategi dan media promosi untuk memasarkan Yayasan Nurul Ihsan;

2. Diskusi dua arah, bertujuan menyamakan persepsi agar tidak ada perbedaan maksud yang diinginkan dengan apa yang hendak dilakukan;

3. Studi kasus, menentukan permasalahan utama yang dihadapi Yayasan Nurul Ihsan dalam upaya pengembangannya;

4. Evaluasi, bertujuan melihat sejauh mana dampak atau kefektifan media promosi yang dipiluh nantinya

\section{HASIL DAN PEMBAHASAN}

Promosi merupakan kegiatan terpenting, yang berperan aktif dalam memperkenalkan,memberitahukan dan mengingatkan kembali manfaat suatu produk agar mendorong konsumen untuk membeli produk yang dipromosikan tersebut. Untuk mengadakan promosi, setiap perusahaan harus dapat menentukan dengan tepat alat promosi manakah yang dipergunakan agar dapat mencapai keberhasilan dalam penjualan. Menurut Nickels dalam Swastha \& Irawan (2008:349), promosi adalah arus informasi atau persuasi satu arah yang dibuat untuk mengarahkan seseorang atau organisasi kepada tindakan yang menciptakan pertukaran dalam pemasaran.

Metode-metode yang digunakan dalam kegiatan promosi tersebut terdiri atas periklanan, promosi penjualan, penjualan perseorangan dan hubungan masyarakat. Promosi menunjuk pada berbagai aktivitas yang dilakukan perusahaan untuk mengkomunikasikan kebaikan produknya dan membujuk para pelanggan dan konsumen sasaran untuk membeli produk tersebut. Sehingga dapat disimpulkan mengenai promosi yaitu dasar kegiatan promosi 
adalah komunikasi perusahaan dengan konsumen untuk mendorong terciptanya penjualan. Banyak jenis media yang dapat digunakan untuk mempromosikan produk, baik barang maupun jasa. Berikut jenis media tersebut :

1. Koran/surat kabar, biasanya relatif tidak mahal, sangat fleksibel, dapat dinikmati lebih lama. Namun memiliki kekurangan mudah diabaikan, dan terkadang dianggap tidak penting;

2. Majalah, dapat dinikmati lebih lama, pembacanya lebih selektif, dapat mencantumkan dengan menggunakan gambar yang menarik. Namun memiliki biaya yang relatif lebih mahal dan fleksibilitasnya rendah;

3. Televisi, dapat dinikmati oleh siapa saja, waktu dan acara siarannya sudah tertentu, dapat memberikan kombinasi antara gambar yang bergerak. Namun memiliki kekurangan biayanya relatif lebih mahal, dapat dinikmati sebentar, dan kurang fleksibel.

4. Radio, biayanya relatif murah, dapat diterima oleh siapa saja, dan juga dapat menjangkau daerah luas Waktunya terbatas, namun tidak dapat mengemukakan gambar, pendengar sering kurang mendengar secara penuh karena sambil melakukan pekerjaan.

5. Media sosial,biaya relatif jauh lebih murah dibanding media promosi sebelumnya, namun memerlukan penanganan atau pengelolaan yang lebih aktif

Promosi merupakan kegiatan yang ditujukan untuk mempengaruhi konsumen agar mereka menjadi kenal terhadap produk yang ditawarkan oleh perusahaan yang kemudian mereka menjadi senang lalu membeli produk tersebut. Menurut Kotler, promosi atau komunikasi pemasaran terdiri atas empat sarana atau alat yang penting yaitu periklanan (advertising), publisitas (publicity), dan penjualan pribadi (personal selling). Periklanan (advertising) Iklan adalah setiap bentuk komunikasi nonpersonal mengenai suatu organisasi, produk, servis, atau ide yang dibayar oleh satu sponsor yang diketahui. Iklan merupakan salah satu bentuk promosi yang paling dikenal dan paling banyak dibahas orang, hal ini memungkinkan karena daya jangkauannya yang luas. Iklan juga menjadi instrumen promosi yang sangat penting, khususnya bagi perusahaan yang memproduksi barang atau jasa yang ditujukan kepada masyarakat luas. Berikut ini adalah pilihan strategi promosi yang dipilih oleh Yayasan Nurul Iksan dalam pengembangannya :

1. Melakukan kerja sama dengan pengusaha atau rekan dalam pemasangan iklan, seperti mengirimkan penawaran produk kepada para donatur atau memberikan potongan harga bagi pembelian produk yang dihasilkan para santri.

2. Memperkenalkan produk dan usaha melalui beberapa media gratis. Hal ini bertujuan untuk membantu pencarian para konsumen mengenai produk apa saja yang ditawarkan, seperti publikasi melalui internet (media sosial) dengan melibatkan lingkungan yang berada di sekitar usaha.

3. Publisitas, yang bertujuan mempengaruhi secara tidak langsung kepada konsumen agar mereka menjadi tahu dan menyenangi produk yang dipasarkannya. Cara ini dilakukan dengan cara membuat berita kegiatan sehari-hari yang dilakukan para santri atau pengurus yayasan.

4. Pendekatan Emosional Marketing dilakukan dalam upaya mencari calon donatur baru atau meningkatkan produktifitas donatur lama.Hal ini biasanya dilakukan seperti sering mengajak komunikasi donatur atau calon donatur, atau dengan pemberian sesuatu yang bisa menimbulkan simpati dari donatur. 


\section{KESIMPULAN DAN SARAN}

\section{Simpulan}

1. Silaturahmi bertujuan menjalin suatu kekeluargaan yang akan menciptakan suatu kepercayaan bagi donatur atau calon donatur. Agar terjalin pendekatan emosional yang loyal kepada donatur atau calon donatur.

2. Tenaga pemasaran (para santri \& pengurus yayasan) harus terus disemangati setiap hari misal dengan bertanya kesulitan apa dalam menghadapi donatur.

3. Bertanggung jawab dan amanah untuk mengelola dana dari donatur sehingga Yayasan Nurul Ihsan memperoleh citra yang baik dari anggota dan masyarakat.

4. Media cetak seperti brosur dan media sosial (whatsup, instagram dan facebook dapat digunakan untuk lebih mengenalkan Yayasan Nurul Ihsan kepada masyarakat luas.

\section{Saran}

Pemasaran merupakan salah satu hal penting yang harus dilakukan ketika menjalankan sebuah usaha, baik usaha baru maupun usaha lama yang telah dirintis bertahun-tahun lamanya. Setelah menentukan strategi pemasaran yang efektif dalam mengembangkan Yayasan, para santri dan pengelola yang ditunujuk diberikan bekal/keterampilan sebagai seorang sales atau penjual yang profesional.Salah satu keterampilan tersebut adalah kemampuan berkomunikasi dalam menyampaikan produk yang dimiliki.

\section{Ucapan Terima Kasih}

Puji syukur kami panjatkan kehadirat Allah SWT, karena telah memberikan rahmatNya sehingga kami dapat menyelesaikan kegiatan Pengabdian Kepada Masyarakat (PKM) dengan dengan baik. Terima kasih juga kami ucapkan kepada : Rektor Universitas Pamulang, Dekan Fakultas Ekonomi - Universitas Pamulang, Kepala Prodi Manajemen - Universitas Pamulang, Kepala LPPM - Universitas Pamulang, Ketua Yayasan Nurul Iksan dan Semua pihak yang telah berkontribusi dengan memberikan ide-idenya sehingga laporan akhir ini dapat diselesaikan. Kami menyadari hasil PKM ini masih jauh dari sempurna dan masih banyak kekurangannya, oleh karena itu kami mohon saran dan kritiknya untuk pengembangan PKM selanjutnya. Dengan segala kerendahan hati kami juga berharap semoga hasil PKM ini dapat bermanfaat sebagai sumbangan pemikiran bagi masyarakat serta praktisi maupun akademisi

\section{DAFTAR PUSTAKA}

Alma, B. (2014). Manajemen Pemasaran dan Pemasaran Jasa. Bandung: Alfabeta.

Kotler, P. (2012). Manajemen Pemasaran di Indonesia :Analisis,. Perencanaan, Implementasi dan Pengendalian. Jakarta : Penerbit Salemba.

Rangkuti, F. (2012). The Power of Brand. Jakarta: PT Gramedia Pustaka Utama.

Tjiptono, F \& Gregorius C. (2011). Service, Quality \& Satisfaction. Edisi 3. Yogyakarta: ANDI. 